\section{Questión}

Periodismo / Comunicación ISSN 1669-6581
- Av. $44 \mathrm{~N}^{\circ} 676,1^{\circ}$ piso

CP 1900 - La Plata - Argentina

( www.perio.unlp.edu.ar/question

Ecuador: la situación no está controlada

Claudia Roura

https://doi.org/10.24215/16696581e393

\title{
Ecuador: La situación no está controlada
}

\section{Ecuador: The situation is not controlled}

\begin{abstract}
Periodista Ecuatoriana. Reportera y Anchor del programa de opinión Políticamente Correcto de Ecuavisa. Conductora del segmento del radio Cuentas Claras y en TV de Economía Correcta.

@ClaudiaRoura
\end{abstract}

\section{Palabras Claves}

Pandemia - Comunicación - Reporte

\section{Key Words}

Pandemic - Communication - Report

\section{Enlace}

https://ar.ivoox.com/es/51717691 